\title{
Niche overlap and diet breadth in bumblebees; are rare species more specialized in their choice of flowers?
}

\author{
Dave GOULSON*, Ben DARVILL \\ Division of Biodiversity and Ecology, School of Biological Sciences, Biomedical Sciences Building, \\ Bassett Crescent East, Southampton SO16 7PX, UK
}

(Received 4 November 2002; revised 23 May 2003; accepted 10 July 2003)

\begin{abstract}
The ecology of all bumblebees (Bombus spp.) is similar, yet some species have declined greatly while others remain abundant. We examine whether abundance is related to diet breadth. The floral visits of bumblebees were examined on Salisbury Plain, UK. All of the species examined gathered pollen mostly from Fabaceae. All species gathered nectar from a broader range of flowers than they did pollen, and longertongued bees had a narrower diet breadth when collecting nectar. B. hortorum (the species with the longest tongue) specialized on Trifolium pratense. As predicted, abundant species had a broader diet than rare species. Species with similar-length tongues visiting similar flowers. However, interspecific competition did not appear to be important since species with similar tongue lengths and high niche overlap co-occurred at high abundance. We suggest that the rare species may be those with short colony cycles, in which dependence on high quality food to rear larvae quickly forces specialization.
\end{abstract}

Hymenoptera / Bombus / rarity / tongue length / pollen / competition

\section{INTRODUCTION}

Many bumblebee (Bombus) species have declined dramatically in recent decades, both in Europe and in North America (Peters, 1972; Williams, 1982, 1986; Rasmont, 1995; Kosior, 1995; Buchmann and Nabhan, 1996; Westrich, 1996; Westrich et al., 1998). Of the 25 species known from the UK, three species are extinct and several more are now confined to a handful of sites and have uncertain futures. The consensus is that declines in numbers of bumblebees are linked to the intensification of farming practices (Williams, 1986; Osborne and Corbet, 1994). However, a small subset of species (6 in the UK) have proved to be at least partially immune to these changes; their ranges have not contracted, and they remain abundant and ubiquitous.
In general, it seems that those species with restricted geographic ranges also tend to be less abundant where they do occur (Williams, 1986). At present we have no indication as to why bumblebee species differ so widely in their range, abundance, and susceptibility to environmental change. Morphologically, all species are remarkably similar, the only obvious differences being variation in size and tongue length. They have broadly similar annual life cycles (although a few species are partially bivoltine), and all depend exclusively on nectar and pollen for food. Most species do not have precise habitat requirements, so far as is known (Williams, 1986).

The plight of our bumblebee fauna deserves particular attention because loss of bee species will have negative consequences for other wildlife. A large number of wild plants are

\footnotetext{
* Corresponding author: DG3@ soton.ac.uk
} 
pollinated predominantly or exclusively by bumblebees, sometimes by particular species of bumblebee (Corbet et al., 1991; Osborne et al., 1991). Thus it seems probable that reductions in the abundance and species richness of bumblebees may lead to widespread changes in plant communities (Corbet et al., 1991). And of course these changes will have further knock-on effects for associated herbivores and other animals dependent on plant resources.

For practical reasons, most studies of bumblebee ecology and behaviour focus on the common species, notably B. terrestris, B. lucorum, B. lapidarius, B. pratorum, B. pascuorum and $B$. hortorum in Europe. For most of the approximately 40 remaining European bumblebee species, we have very little information on foraging preferences, or indeed on any other aspect of their ecology. We do not know whether the behaviour and foraging preferences of the common species are representative of all bumblebees. The reverse may be true; the common species are probably common because they are atypical generalists. If this is so, then our knowledge of common species may be of little help in conserving the rare ones. Ecological studies of rare and declining species are urgently needed if appropriate conservation measures are to be deployed. Here we examine whether rarity in bumblebees is related to specialization in flowers utilized. We test the prediction that rare species tend to be more specialized in terms of the flowers that they visit. We also examine whether diet breadth and niche overlap between species relates to tongue-length.

\section{METHODS}

The study was carried out on Salisbury Plain Training Area (SPTA), southern UK, the largest area of unimproved chalk grassland that remains in north-west Europe. Its status as a military training area since 1897 has protected it from most of the farming changes that have occurred elsewhere, and much of its 38000 ha consists of lightly grazed flower-rich grassland and scrub. As a result, it supports a diverse bumblebee assemblage, with at least 16 species present, perhaps the most that occur at any UK site (Carvell, 2002). It thus provides an opportunity to compare the forage used by both common and rare species when foraging in the same habitat.
Studies were carried out between 19 July and 13 August 2002. This is late for some bumblebee species, but facilitated access since all live firing ceases on SPTA for two weeks in early August. Thirty five sites were selected to cover the extent of SPTA, with each site at least $1.5 \mathrm{~km}$ from any other. All sites lay between $51^{\circ} 06^{\prime}$ and $51^{\circ} 20^{\prime} \mathrm{N}$ and $1^{\circ}$ $40^{\prime}$ and $2^{\circ} 00^{\prime} \mathrm{W}$, and were between 150 and $200 \mathrm{~m}$ altitude. Each site consisted of a circle of approximately $100 \mathrm{~m}$ radius, and was searched for one hour. All searches were conducted between $0900 \mathrm{~h}$ and $1700 \mathrm{~h}$, and during warm dry weather favourable to bee activity. All Bombus species were recorded. No attempt was made to distinguish workers of B. terrestris and B. lucorum (to do so would have been very time-consuming and unreliable in the field). B. humilis and B. muscorum are indistinguishable on the wing, so all specimens of these species were captured and examined with a hand lens. Any other individuals that could not be readily identified were also captured, notably Psithyrus spp. and B. ruderarius. The area was searched systemically, to avoid recording the same bees more than once, but this probably occasionally occurred. Most bees were visiting flowers. The flower species visited was recorded, and the bee was briefly observed to determine whether it was collecting pollen or nectar. Bees were classified as nectar collectors (those not collecting pollen) or pollen collectors (those observed actively grooming pollen into their corbiculae), but it must be noted that most pollen collectors were also collecting nectar. The total number of inflorescences within the search area (the circle of $100 \mathrm{~m}$ radius) was estimated by eye for each forage species present.

To compare the diet breadth of the species recorded, a Simpson's index was calculated for the diversity of flowers visited (Simpson, 1949):

$$
D_{s}=\sum_{i=1}^{s} \frac{\left(n_{i}\left(n_{i}-1\right)\right)}{(N(N-1))}
$$

where $n_{i}$ is the number of flowers of the $i$ th species that were visited, $\mathrm{N}$ is the total number of flowers visited, and $s$ is the total number of flower species visited. As is usual, results are presented as $1 / \mathrm{D}$, so that larger values indicate higher diversity. This index is insensitive to sample size (Magurran, 1988) which is important because samples are inevitably larger for the more common species. Only workers were included in the calculation, and only species for which there were at least 10 records of both pollen and nectar collection. It must be noted that the combined index for B. terrestris and B. lucorum is likely to overestimate the true value for these two species, if the two species have different preferences. Spearman's rank correlations were calculated to examine relationships between total abundance (workers, queens and males combined) and diversity indices. 


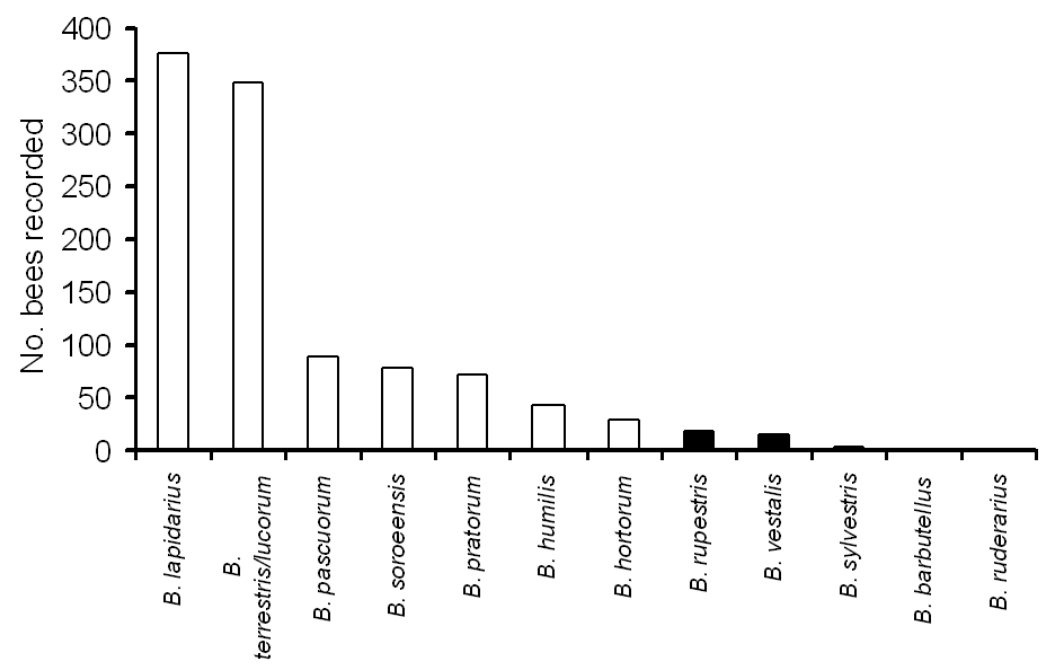

Figure 1. Abundance of Bombus species recorded on Salisbury Plain (all sites combined). Numbers include all individuals (workers, queens and males). Members of the subgenus Psithyrus are indicated by dark bars.

Niche overlap in flower usage was calculated between species pairs for the seven most abundant bumblebee species (treating $B$. terrestris and $B$. lucorum as one), following Colwell and Futuyma (1971). A separate measure was calculated for pollen and nectar collection.

Niche overlap between bee species $i$ and $h=$

$$
1-0,5 \sum_{k}\left(P_{i k}-P_{h k}\right)
$$

where

$$
P_{i k}=\frac{\text { No. bee species } i \text { visiting plant species } k}{\text { Total No. bee species } i}
$$

Tongue lengths were measured for ten workers of each species (length of the glossa plus prementum, following Prys-Jones and Corbet (1991)). Workers of B. terrestris and B. lucorum did not differ significantly in tongue length, so they were pooled. To examine whether niche differentiation in either nectar or pollen collection could be explained by differences in tongue length between species, the relationship between niche overlap and tongue length between each species pair was examined with a Mantel test with 10000 runs, using Mantel V2.0, shareware, by Adam Liedhoff (Manly, 1986).

\section{RESULTS}

In total, 13 Bombus species were recorded (1 061 individuals), visiting flowers of 33 different species. By far the most common bumblebee species was $B$. lapidarius, followed by the combined category of B. terrestris/lucorum (Fig. 1). The three other species known to be widespread and abundant in the UK, B. pascuorum, B. pratorum and B. hortorum (Williams, $1985,1986)$ were all recorded in moderate numbers. More interestingly, two rare species, B. soroeensis and B. humilis, were found to be widely distributed and moderately abundant.

For all species combined, $76.0 \%$ of pollencollecting visits were to members of the Fabaceae: notably Onobrychis viciifolia, Melilotus cf. altissimus and Trifolium pratense. The only other substantial pollen source was Odontites vernus (Scrophulariaceae), which received $11.0 \%$ of visits (Fig. 2). Patterns of forage usage did not closely follow abundance of plant species (Fig. 3). The species that received the most visits overall ( $T$. pratense and $O$. viciifolia) were not especially abundant.

There was a correlation between the abundance of species and their diet breadth when collecting pollen (Spearman's rho $=0.929$, $P=0.003$, Tab. I). The two most abundant species (both in this study and nationally), $B$. lapidarius and B. terrestris/lucorum had the broadest diet (collecting pollen from 15 and 17 plant species, respectively). In contrast $B$. hortorum had the narrowest diet, specializing almost entirely on $T$. pratense $(82.0 \%$ of visits). B. pratorum also exhibited a high degree 


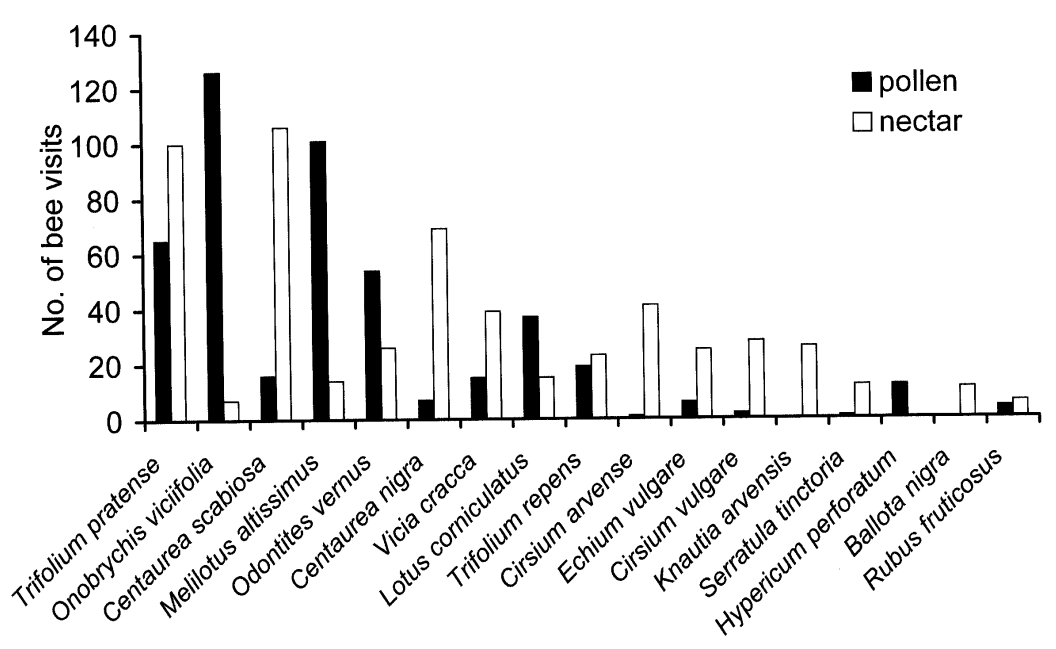

Figure 2. Numbers of visits recorded to different flowers, according to whether pollen or nectar was collected (for all bee species combined, including males and members of the subgenus Psithyrus). Only plants for which at least ten visits in total were recorded are included.

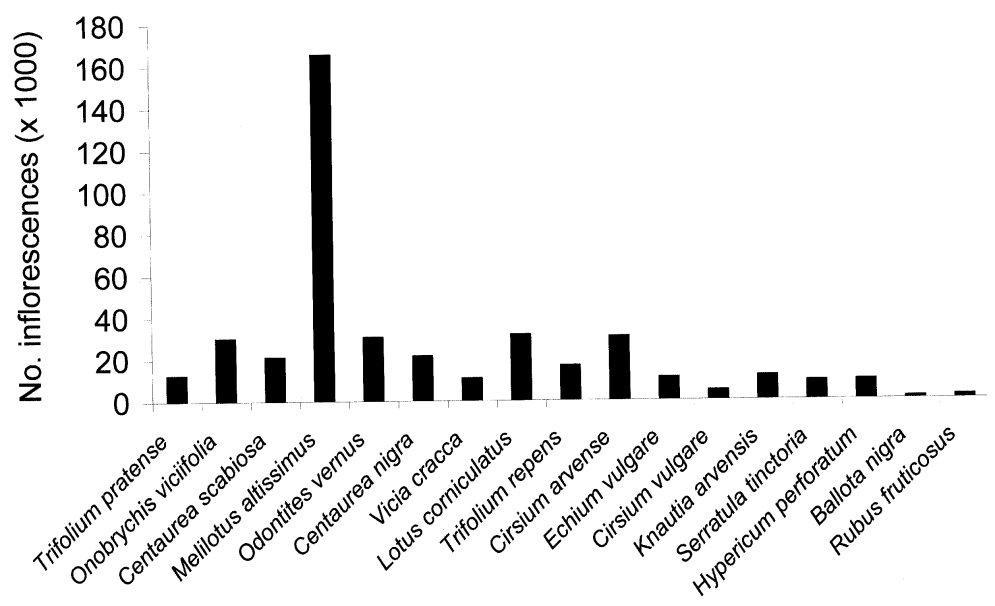

Figure 3. Total numbers of inflorescences recorded for the 17 plant species that received most bumblebee visits at the study sites on Salisbury Plain (summed for all 35 search areas, each a circle of $100 \mathrm{~m}$ radius). Species are ordered according to bumblebee visitation, with the species that were visited most on the left (as in Fig. 2).

of specialization in pollen collection, almost exclusively visiting $M$. cf. altissimus and $O$. vernus $(44.7 \%$ and $50.0 \%$ of visits, respectively). $B$. humilis appeared to specialize in gathering pollen from the Fabaceae $(92.6 \%$ of visits), but visited several species within this family.

For all species examined, Simpson's index for the diversity of flowers visited by workers was lower when collecting pollen than when collecting nectar (Tab. I) (Wilcoxon signed ranks test, $\mathrm{z}=0.237, P=0.018$ ). While pollencollecting visits were mostly to Fabaceae, nectar collection occurred across a broader range of species, mostly within the Fabaceae, Asteraceae, Scrophulariaceae and Boraginaceae. Notable favourites were Centaurea scabiosa, Centaurea nigra (Asteraceae) and T. pratense. 
Table I. Tongue length, and Simpson's index for the diversity of flowers visited when collecting pollen and nectar, for workers of 8 bumblebee species in grassland in southern UK.

\begin{tabular}{lcccc}
\hline & Pollen & Nectar & N & $\begin{array}{c}\text { Tongue length } \\
\text { (mean } \pm \text { SD, mm) }\end{array}$ \\
\hline B. terrestris/lucorum & 5.26 & 9.28 & 323 & $7.9 \pm 0.5$ \\
B. lapidarius & 5.72 & 7.96 & 247 & $7.8 \pm 0.4$ \\
B. pascuorum & 4.07 & 4.35 & 85 & $8.5 \pm 0.6$ \\
B. hortorum & 1.52 & 3.62 & 26 & $12.9 \pm 0.8$ \\
B. pratorum & 2.28 & 12.7 & 67 & $7.3 \pm 0.4$ \\
B. humilis & 2.70 & 2.75 & 39 & $8.4 \pm 0.5$ \\
B. soroeensis & 4.77 & 8.14 & 42 & $7.3 \pm 0.4$ \\
\hline
\end{tabular}

Table II. Niche overlap between species pairs, when collecting pollen (lower left) or nectar (upper right).

\begin{tabular}{lccccccc}
\hline & $\begin{array}{c}\text { B. terrestris/ } \\
\text { lucorum }\end{array}$ & B. lapidarius & B. pascuorum & B. hortorum & B. humilis & B. soroeensis & B. pratorum \\
\hline B. terrestris/lucorum & $*$ & 0.708 & 0.444 & 0.321 & 0.339 & 0.276 & 0.389 \\
B. lapidarius & 0.694 & $*$ & 0.414 & 0.314 & 0.377 & 0.319 & 0.248 \\
B. pascuorum & 0.224 & 0.303 & $*$ & 0.641 & 0.631 & 0.185 & 0.318 \\
B. hortorum & 0.057 & 0.116 & 0.406 & $*$ & 0.600 & 0.186 & 0.370 \\
B. humilis & 0.300 & 0.412 & 0.699 & 0.593 & $*$ & 0.136 & 0.103 \\
B. soroeensis & 0.559 & 0.493 & 0.387 & 0.087 & 0.266 & $*$ & 0.503 \\
B. pratorum & 0.372 & 0.171 & 0.308 & 0 & 0.137 & 0.505 & $*$ \\
\hline
\end{tabular}

There was no significant relationship between bee abundance and the diet breadth when collecting nectar (Spearman's rho $=0.429$, n.s.). B. humilis showed most specificity, visiting mostly Fabaceae, particularly $T$. pratense and Lotus corniculatus (63.6 and $27.3 \%$ of visits, respectively). In contrast $B$. soroeensis visited a range of flowers, mainly within the Fabaceae and Asteraceae. Notably, by far the most polylectic species was B. pratorum which, despite not being particularly abundant, was recorded collecting nectar from 13 different flower species.

Overall, niche overlap when collecting pollen was strongly correlated with niche overlap when collecting nectar (Mantel test, $g=2.83$, $P<0.05$, Tab. II). There was a strong negative relationship between niche overlap and the difference in tongue length between species for pollen collection $(\mathrm{g}=-2.38, P<0.01)$, but not for nectar collection ( $g=-0.184$, ns, Fig. 4).

There was a significant tendency for longtongued species to have narrower diet breadth when collecting nectar, but not when collect- ing pollen (Spearman's rho $=0.757, P=0.049$ and rho $=0.378$, ns, respectively).

Too few males were recorded of most species to compare their foraging preferences. The majority of the 215 males recorded were of B. lapidarius (113), and B. terrestris (48). The only other species recorded in moderate numbers were $B$. lucorum (16), B. vestalis (13) and $B$. rupestris (13). The vast majority of visits were to Centaurea spp. (132/215) or Cirsium spp. (45/215). For these 5 species of bumblebees, there was little sign of niche differentiation in males.

\section{DISCUSSION}

Our results suggest that all of the bumblebees in the study area are largely reliant on a rather small number of plant species. Despite the floristic diversity on Salisbury plain, 65\% of all flower visits by bumblebees were to just 6 plant species. In particular, pollen was collected overwhelmingly from Fabaceae (76\% of visits). Some species, notably B. humilis, 

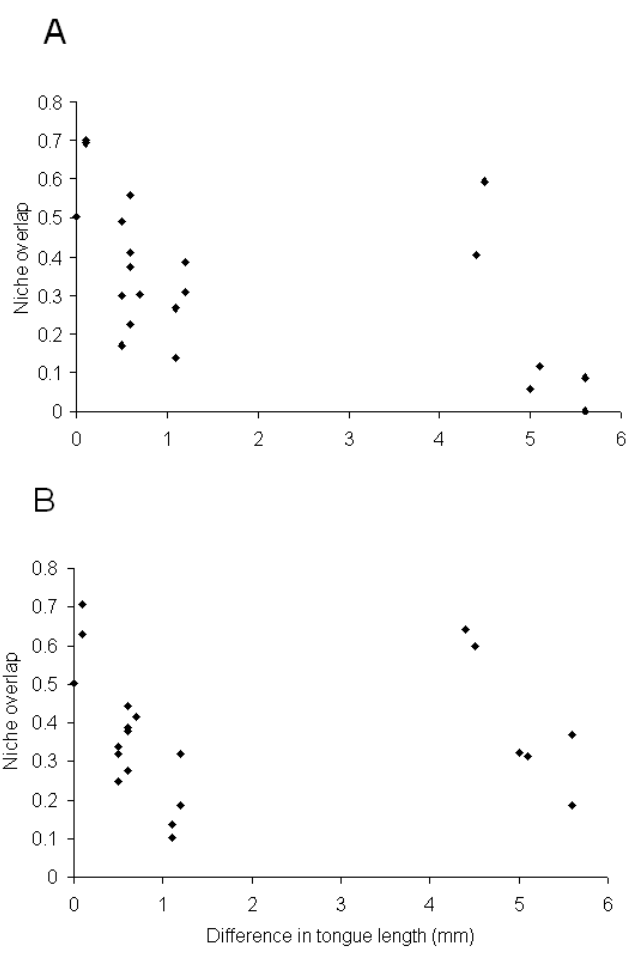

Figure 4. Relationship between niche overlap and difference in tongue length for seven species $(B$. terrestris/lucorum, B. lapidarius, B. pascuorum, $B$. pratorum, B. humilis, B. hortorum and B. soroeensis). (A) pollen collection; (B) nectar collection.

gathered pollen almost exclusively from Fabaceae, while B. hortorum was even more specific, gathering pollen largely from just one species, T. pratense. Brian (1951) found that pollen from T. pratense made up 74\% of larval food in B. hortorum nests in Scotland, and studies in Finland, Sweden and Denmark all suggest the importance of $T$. pratense for this bumblebee species (Skovgaard, 1936; Teräs, 1985; Jennersten et al., 1988). Most recently, Carvell (2002) found a strong correlation between abundance of $T$. pratense and abundance of both $B$. hortorum and $B$. humilis on SPTA. It is not known why Fabaceae are the preferred pollen source for bumblebees in general, nor why some bumblebees are more specific in their pollen requirements than others.

There was a clear relationship between abundance and diet breadth. The more abundant species (B. terrestris/lucorum, B. lapidar- ius and $B$. pascuorum) were markedly less selective in their choice of pollen source than the rarer species in this study. It is perhaps not surprising that widespread and abundant species are more generalized. These four most abundant species all emerge from hibernation early (in March, sometimes before) and have long colony cycles of approximately 16-25 weeks (Alford, 1975; Goodwin, 1995), so perhaps rapid larval development on high quality food is not needed. By generalizing, they gain access to a large amount of pollen. In contrast, species such as $B$. humilis and $B$. hortorum emerge from hibernation in May, and so their colonies have less time in which to develop and rear reproductives (approx. 14 weeks for B. hortorum, Goodwin, 1995). B. pratorum, the other species that gathered pollen from a narrow range of plant species, also has shortlived colonies although it emerges from hibernation earlier (Goodwin, 1995). The necessity for rapid colony development may force these species to provide the highest quality food for their brood.

Simpson's indices for diversity of floral resources used were consistently higher for nectar collection compared to pollen collection, across all bumblebee species, suggesting that this may be a general phenomenon. Nectar was collected from several plant families, primarily Fabaceae and Asteraceae, but also Scrophulariaceae, Boraginaceae and Lamiaceae, in accordance with previous studies (Fussell and Corbet, 1992). Since nectar consists almost entirely of sugar and water (in varying proportions), perhaps qualitative differences in the nectar provided by different plants are slight, allowing bumblebees to opportunistically exploit whatever is available.

There are prominent discrepancies in the literature concerning the importance of interspecific competition in shaping bumblebee communities. Resource partitioning with respect to tongue length has long been thought to be an important factor in allowing North American bumblebee species with otherwise very similar biology to coexist (Heinrich, 1976; Pyke, 1982; Inouye, 1978, 1980; Harder, 1985; Johnson, 1986; Graham and Jones, 1996). But studies in Europe have failed to find such clear patterns. North and Central European bumblebee communities commonly consist of six to eleven species, with considerable overlap in tongue lengths 
(Ranta et al., 1980; Ranta and Vepsäläinen, 1981). In the UK, the six bumblebee species that are abundant, widespread, and generally occur together includes four with short tongues of very similar length $(B$. terrestris, $B$. lucorum, B. lapidarius and B. pratorum). Several studies of local assemblages of European bumblebees have failed to find any pattern in the tongue lengths of species in relation to their cooccurrence (Ranta, 1982, 1983; Ranta and Tiainen, 1982; Williams, 1985, 1988). Our data suggest that differences in tongue length do lead to niche partitioning, particularly when collecting pollen. This is unexpected, since tongues are not used in pollen collection. However, pollen collectors often simultaneously collect nectar, which may explain this pattern. What is more surprising is that there was no significant relationship between niche overlap when collecting nectar and differences in tongue length. When collecting nectar, B. hortorum had similar floral preferences to $B$. pascuorum and $B$. humilis, despite having a tongue which is very much longer (the points on the right of Fig. 3). The advantage of a very long tongue is presumably that it allows access to nectar in flowers with very deep corollas which other bees cannot reach. Perhaps, at the time of our study, such flowers were scarce or absent.

A notable feature of our data is that species with similar length tongues and high niche overlap in floral preferences co-occur at high densities (notably B. lapidarius, B. terrestris and $B$. lucorum). This suggests that competition for floral resources is not a powerful force in these bumblebee communities, at least at this time of year.

To summarise, we demonstrate that bumblebees do vary in their degree of specialization, particularly with regard to pollen sources. This appears to correlate with abundance, with less abundant species being more specialized. Analysis of the nutritive value of pollen from different plants would be informative in determining why Fabaceae appear to be a preferred pollen source, particularly for rarer bees.

\section{ACKNOWLEDGEMENTS}

This work was funded by a grant from the British Entomology and Natural History Society to DG. We would like to thank Defence Estates for allowing access to SPTA.
Résumé - Chevauchement de niches et étendue du régime alimentaire chez les bourdons : les espèces rares sont-elles plus spécialistes dans le choix des fleurs? De nombreuses espèces de bourdons (Bombus L.) ont régressé de façon alarmante ces 50 dernières années mais certaines d'entre elles restent néanmoins abondantes. L'écologie et la morphologie de toutes les espèces de bourdons est en gros semblable et nous ne savons pas pourquoi certaines espèces sont plus affectées que d'autres par les modifications de milieu. Nous quantifions ici le butinage d'un ensemble d'espèces communes et rares et examinons si l'abondance de l'espèce est liée à l'étendue de son régime.

Les visites florales des bourdons ont été observées dans la plaine de Salisbury, la plus grande prairie calcaire d'Europe occidentale riche en fleurs. La diversité des espèces de bourdons y est inhabituellement élevée, ce qui nous a permis d'obtenir des données sur les préférences de butinage d'espèces rares. Les études ont été menées entre le 19 juillet et le 13 août 2002. Trente cinq sites ont été choisis, chaque site consistant en en cercle de $100 \mathrm{~m}$ de rayon étudié pendant $1 \mathrm{~h}$. Toutes les espèces de Bombus ont été enregistrées, ainsi que les espèces florales visitées. On a déterminé si l'insecte récoltait du nectar ou du pollen. Au total on a enregistré 13 espèces de bourdons (1061 individus) visitant 33 plantes différentes (Figs. 1 et 2).

Nos résultats suggèrent que toutes les espèces de bourdons de l'aire d'étude dépendaient grandement d'un petit nombre d'espèces végétales. $65 \%$ des visites faites par les bourdons concernaient seulement 6 espèces végétales. 76,0 \% des visites pour récolter du pollen concernaient la famille des Fabaceae, particulièrement Onobrychis sativa, Melilotus cf. altissimus et Trifolium pratense. La seule autre source de pollen importante était Odontites vernus (Scrophulariaceae), qui recevait 11,0\% des visites. Le degré de spécialisation variait grandement d'une espèce à l'autre. Certaines espèces de bourdons, notamment $B$. humilis, récoltaient du pollen presque uniquement sur les Fabaceae, tandis que B. hortorum était plus spécialiste, ne récoltant du pollen principalement que d'une espèce, $T$. pratense. Le nectar était récolté sur une plus grande variété de fleurs que le pollen par toutes les espèces et les bourdons à langue longue, comme $B$. hortorum, avaient un régime plus étroit que les bourdons à langue courte lorsqu'ils récoltaient du nectar. Comme prédit, les espèces abondantes (B. terrestris/lucorum, $B$. lapidarius et $B$. pascurorum) avaient un régime plus large que les espèces rares (Tab. I). Les espèces ayant la même longueur de langue visitaient le même nombre d'espèces végétales. Un trait remarquable de nos données est que les espèces ayant la même longueur de langue et dont les préférences florales se recouvrent en grande partie co-existent à des fortes densités (notamment $B$. lapidarius, B. terrestris et $B$. lucorum). Cela suggère que la compétition interspécifique pour les ressources florales ne constitue pas une force puissante chez ces communautés de 
bourdons, au moins à cette période de l'année. Nous suggérons que les espèces plus rares peuvent être celles dont des cycles de colonies sont plus courts et pour lesquelles la dépendance d'une nourriture de grande qualité pour élever les larves les contraint rapidement à se spécialiser dans les fleurs visitées.

Bombus / compétition alimentaire / pollen / longueur de langue / abondance écologique

Zusammenfassung - Überlappung von Nischen und Nahrungsspektren bei Hummeln: sind seltene Arten bei der Blütenwahl stärker spezialisiert? Viele Hummelarten sind in den letzten 50 Jahren alarmierend selten geworden, aber eine kleine Anzahl Arten gibt es weiterhin häufig. Die Ökologie und Morphologie aller Hummeln sind weitgehend ähnlich, und wir wissen nicht, warum einige Arten durch die Änderung der Umwelt stärker betroffen sind als andere. Aus praktischen Gründen haben sich die meisten Untersuchungen über die Ökologie der Hummeln auf Arten konzentriert, die es noch häufig gibt - aber diese sind wahrscheinlich nicht repräsentativ für die seltenen Arten. Hier quantifizieren wir die Sammelgewohnheiten von häufigen und seltenen Arten und untersuchen, ob die Häufigkeit bestimmter Hummelarten mit der Vielfalt ihrer Nahrung in Zusammenhang steht. Die Blütenbesuche wurden in der Ebene von Salisbury untersucht, dem größten erhaltenen Gebiet mit blütenreichen Kalkwiesen in West Europa. Die Salisbury Ebene hat eine ungewöhnlich hohe Diversität an Hummelarten, wodurch wir Daten über die Sammelstrategien der seltenen Arten sammeln konnten. Die Versuche wurden zwischen dem 19. Juli und dem 13. August 2002 durchgeführt. Es wurden 35 Bereiche ausgesucht; jeder Bereich umfasste einen Kreis mit einem Radius von 100 m, und wurde für eine Stunde abgesucht. Alle Bombus Arten wurden protokolliert. Die meisten Hummeln besuchten Blüten: Die Blütenart wurde bestimmt und bei jeder Hummel wurde beobachtet, ob sie Pollen oder Nektar sammelte. Insgesamt wurden 13 Bombus Arten beobachtet (1 061 Einzeltiere), die Blüten von 33 verschiedenen Pflanzenarten besuchten. Unsere Ergebnisse lassen vermuten, dass alle Hummeln in diesem Versuchsgebiet weitgehend von einer kleinen Zahl an Pflanzenarten abhängig sind. $65 \%$ aller Blütenbesuche der Hummeln fanden auf nur 6 Pflanzenarten statt.

$76,0 \%$ der Besuche zum Pollensammeln betrafen Arten der Fabaceae: besonders häufig Onobrychis viciifolia, Melilotus cf. altissimus und Trifolium pratense. Die einzige andere bedeutende Pollenquelle war Odontites vernus (Scrophulariaceae), die zu 11,0 \% besucht wurde. Der Grad der Spezialisierung variierte stark zwischen den Arten. Einige Hummelarten, besonders $B$. humilis, sammelte fast nur Pollen von Fabaceae, während $B$. hortorum noch spezifischer war und Pollen zum größten Teil nur von einer Art, T. pratense, sammelte. Alle Arten sammelten Nektar von einer größeren Artenzahl der Pflanzen als Pollen. Hummeln mit langen Zungen, wie $B$. hortorum, hatten bei der Nektaraufnahme ein engeres Blütenspektrum als Hummeln mit kurzen Zungen. Wie bereits erwähnt, hatten die häufigen Arten (B. terrestris/lucorum, B. lapidarius und $B$. pascuorum) ein breiteres Nahrungsspektrum als seltene Arten. Arten mit ähnlicher Zungenlänge besuchten ähnliche Blüten. Als bemerkenswerte Besonderheit in unseren Daten erwies sich, dass Arten mit ähnlicher Zungenlänge und einer entsprechend großen Überschneidung der Nischen in hoher Anzahl zusammen vorkommen (besonders B. lapidarius, $B$. terrestris und $B$. lucorum). Das lässt vermuten, dass interspezifische Konkurrenz bei Blüten keine entscheidende Bedeutung in dieser Hummelgesellschaft hat, zumindest nicht in der untersuchten Jahreszeit. Wir vermuten, dass die seltenen Arten einen kurzen Volkszyklus haben. Damit ergäbe sich eine Abhängigkeit von Futter mit hoher Qualität, um die Larven in kurzer Zeit groß zu ziehen und dadurch würde eine Spezialisierung auf bestimmte ergiebige Blüten notwendig.

\section{Hymenoptera / Bombus / Seltenheit / Zungenlänge / Pollen / Konkurrenz}

\section{REFERENCES}

Alford D.V. (1975) Bumblebees, Davis-Poynter, London.

Brian A.D. (1951) The pollen collection by bumblebees, J. Anim. Ecol. 20, 191-194.

Buchmann S.L., Nabhan G.P. (1996) The Forgotten Pollinators, Island Press, Washington (DC).

Carvell C. (2002) Habitat use and conservation of bumblebees (Bombus spp.) under different grassland management regimes, Biol. Conserv. 103, 33-49.

Colwell R.K., Futuyma D.J. (1971) On the measurement of niche breadth and overlap, Ecology 52, 567-576.

Corbet S.A., Williams I.H., Osborne J.L. (1991) Bees and the pollination of crops and wild flowers in the European Community, Bee World 72, 47-59.

Fussell M., Corbet S.A. (1992) Flower usage by bumblebees - a basis for forage plant management, J. Appl. Ecol. 29, 451-465.

Goodwin S.G. (1995) Seasonal phenology and abundance of early-, mid- and long-season bumble bees in southern England, 1985-1989, J. Apic. Res. 34, 79-87.

Graham L., Jones K.N. (1996) Resource partitioning and per-flower foraging efficiency in 2 bumble bee species, Am. Midl. Nat. 136, 401-406.

Harder L.D. (1985) Morphology as a predictor of flower choice by bumblebees, Ecology 66, 198210.

Heinrich B. (1976) Resource partitioning among some eusocial insects: Bumblebees, Ecology 57, 874-889. 
Inouye D.W. (1978) Resource partitioning in bumblebees: experimental studies of foraging behavior, Ecology 59, 672-678.

Inouye D.W. (1980) The effects of proboscis and corolla tube lengths on patterns and rates of flower visitation by bumblebees, Oecologia 45, 197-201.

Jennersten O., Berg L., Lehman C. (1988) Phenological differences in pollinator visitation, pollen deposition and seed set in the sticky catchfly Viscaria vulgaris, J. Ecol. 76, 1111-1132.

Johnson R.A. (1986) Intraspecific resource partitioning in the bumble bees Bombus ternarius and $B$. pennsylvanicus, Ecology 67, 133-138.

Kosior A. (1995) Changes in the fauna of bumblebees (Bombus Latr.) and cuckoo-bees (Psithyrus Lep.) of selected regions in southern Poland, in: Banaszak J. (Ed.), Changes in Fauna of Wild Bees in Europe, Bydgoszcz, Pedagogical University, pp. 103-111.

Magurran A.E. (1988) Ecological diversity and its management, Princeton University Press, Princeton.

Manly B.F.J. (1986) Randomization and regression methods for testing for associations with geographical, environmental and biological distances between populations, Res. Popul. Ecol. 28, 201218.

Osborne J.L., Corbet S.A. (1994) Managing habitats for pollinators in farmland, Asp. Appl. Biol. 40, 207-215.

Osborne J.L., Williams I.H., Corbet S.A. (1991) Bees, pollination and habitat change in the European community, Bee World 72, 99-116.

Peters G. (1972) Ursachen fur den Rückgang der seltenen heimischen Hummelarten (Hym., Bombus et Psithyrus), Entomol. Ber. 1972, 85-90.

Prys-Jones O.E., Corbet S.A. (1991) Bumblebees, Richmond Publishing Company, Slough.

Pyke G.H. (1982) Local geographic distributions of bumblebees near Crested Butte, Colorado: competition and community structure, Ecology 63, 555-573.

Ranta E. (1982) Species structure of North European bumblebee communities, Oikos 38, 202-209.

Ranta E. (1983) Proboscis length and the coexistence of bumblebee species, Oikos 43, 189-196.
Ranta E., Tiainen M. (1982) Structure in seven bumblebee communities in eastern Finland in relation to resource availability, Holart. Ecol. 5, 48-54.

Ranta E., Vepsäläinen K. (1981) Why are there so many species? Spatio-temporal heterogeneity and northern bumblebee communities, Oikos 36, 28-34.

Ranta E., Lundberg H., Teräs I. (1980) Patterns of resource utilization in two Fennoscandian bumblebee communities, Oikos 36, 1-11.

Rasmont P. (1995) How to restore the Apoid diversity in Belgium and France? Wrong and right ways, or the end of protection paradigm! in: Banaszak $\mathrm{J}$. (Ed.), Changes in Fauna of Wild Bees in Europe, Bydgoszcz, Pedagogical University, pp. 53-64.

Simpson G.H. (1949) Measurement of diversity, Nature 163, 688.

Skovgaard O.S. (1936) Rødkloverens Bestøvning. Humlebier og Humleboer. Det Kongelige Danske Videnskabernes Selskabs Skrifter Naturvidenskabelig og Mathematisk Afdeling. 9, Raekke 6, 1-140.

Teräs I. (1985) Food plants and flower visits of bumble-bees (Bombus: Hymenoptera, Apidae) in southern Finland, Acta Zool. Fenn. 179, 1-120.

Westrich P. (1996) Habitat requirements of central European bees and the problems of partial habitats. in: Matheson A., Buchmann S.L., O'Toole C. Westrich P., Williams I.H. (Eds.), The conservation of bees, Academic Press, London, pp. 2-16.

Westrich P., Schwenninger H.-R., Dathe H., Riemann H., Saure C., Voith J., Weber K. (1998) Rote Liste der Bienen (Hymenoptera: Apidae), in: Rote Liste Gefährdeter Tiere Deutschlands, Bundesamt für Naturschutz (Ed.), Naturschutz 55, Bonn, Schriftenr. Landschaftspf, pp. 119-129.

Williams P.H. (1982) The distribution and decline of British bumble bees (Bombus Latr), J. Apic. Res. 21, 236-245.

Williams P.H. (1985) On the distribution of bumble bees (Hymenoptera, Apidae), with particular regard to patterns within the British Isles, Ph.D. thesis, University of Cambridge, UK, $180 \mathrm{p}$.

Williams P.H. (1986) Environmental change and the distribution of British bumble bees (Bombus Latr.), Bee World 67, 50-61.

Williams P.H. (1988) Habitat use by bumble bees (Bombus spp.), Ecol. Entomol. 13, 223-237. 